\title{
An Amino Acid Deletion in Wheat streak mosaic virus Capsid Protein Distinguishes a Homogeneous Group of European Isolates and Facilitates Their Specific Detection
}

\author{
Sébastien Gadiou, Department of Virology, Crop Research Institute, Prague 6-Ruzyně, Czech Republic; Otakar \\ Kúdela, Institute of Virology, Slovak Academy of Sciences, 84505 Bratislava, Slovakia; Jan Ripl, Department of \\ Virology, Crop Research Institute, Czech Republic and Department of Plant Protection, Czech University of Life \\ Sciences Prague, Czech Republic; Frank Rabenstein, Julius Kühn-Institute, Federal Research Centre for Cultivated \\ Plants-Institute for Epidemiology and Pathogen Diagnostics, D-06484 Quedlinburg, Germany; Jiban K. Kundu, \\ Department of Virology, Crop Research Institute, Czech Republic; and Miroslav Glasa, Institute of Virology, Slovak \\ Academy of Sciences, Slovakia
}

\begin{abstract}
Gadiou, S., Kúdela, O., Ripl, J., Rabenstein, F., Kundu, J. K., and Glasa, M. 2009. An amino acid deletion in Wheat streak mosaic virus capsid protein distinguishes a homogeneous group of European isolates and facilitates their specific detection. Plant Dis. 93:1209-1213.

The tritimovirus Wheat streak mosaic virus (WSMV) is widespread throughout the world and represents a severe threat to cereal crop production. To increase knowledge of genetic diversity of WSMV in Europe, until now scarce, capsid protein (CP) sequences of several Czech, French, Italian, Slovak, and Turkish isolates have been determined. A multiple alignment of CP nucleotide sequences using available WSMV sequences revealed only limited sequence variation among 3 previously sequenced European isolates and the 14 European isolates sequenced in this study. Moreover, these isolates were characterized by an identical 3-nucleotide deletion, resulting in the lack of the $\mathrm{Gly}_{2761}$ codon within the $\mathrm{CP}$ region of the polyprotein. The results indicate that this monophyletic group of isolates (designated as WSMV- $\Delta \mathrm{E}$ ) is common and widely dispersed throughout the European continent. The close relationship of WSMV- $\Delta \mathrm{E}$ isolates implies a single common ancestor and, presumably, subsequent dispersal throughout Europe from a single focus. We developed two simple assays for specific and accurate detection of WSMV- $\Delta \mathrm{E}$ isolates. First, a conserved $\mathrm{ClaI}$ restriction site in the core $\mathrm{CP}$ gene sequence unique to WSMV$\Delta \mathrm{E}$ isolates was used for restriction fragment length polymorphism analysis of amplified polymerase chain reaction (PCR) products. Second, the conserved and specific codon gap in WSMV$\Delta \mathrm{E}$ sequences was used as a target to design specific primers functional in one-step reversetranscription PCR detection of WSMV- $\Delta \mathrm{E}$ isolates.
\end{abstract}

Wheat streak mosaic virus (WSMV) is the type member of the genus Tritimovirus within the family Potyviridae (25). The WSMV genome is a single-stranded plussense RNA of 9,339 to 9,384 nucleotides (nt) translated as a single polyprotein. Up to 10 mature proteins are derived from the polyprotein following processing by virusencoded proteinases $(5,6,29)$. The virus is widespread throughout the world and represents a severe threat in most areas of cereal crop production $(21,24)$. WSMV infects many plant species of the family Poaceae (1,9), including wheat (Triticum aestivum L.), oat (Avena sativa L.), barley (Hordeum vulgare L.), several grasses, and certain cultivars of maize (Zea mays L.) and millet (Panicum, Setaria, and Echinochloa spp.). The virus causes a severe disease impacting wheat production in the

Corresponding author: M. Glasa

E-mail: Miroslav.Glasa@savba.sk

Accepted for publication 5 July 2009.

doi:10.1094/PDIS-93-11-1209

(c) 2009 The American Phytopathological Society western Great Plains of North America; annual production losses of $5 \%$ have been estimated, although severe local WSMV infection can result in yield losses up to $100 \%$ (10). The virus is transmitted by eriophyid mite Aceria tosichella Keifer (Acarina: Eriophyidae) (27). Seed transmission, although at very low rates, also has been described in experimentally infected wheat cultivars (17). The estimated levels of WSMV in seed lots originating from infected commercial wheat crops ranged from 0 to $0.22 \%$, with an overall transmission rate of $0.06 \%$ (20).

Mutation (insertion and deletion included) is a key process for generating genetic diversity. Selection pressure in new or altered environmental conditions results in fixation of mutations that increase fitness (12). Increased knowledge of genetic diversity facilitates understanding of pathogen epidemiology and provides a basis for defining and characterizing virus population structure. Polymorphism in WSMV has been examined previously $(11,15,28,30)$; however, the studies mostly focused on diversity within American and Australian populations. Diversity in European populations of WSMV has received less attention (24). In this work, we have determined partial genome sequences of several naturally occurring WSMV isolates from Europe in an effort to extend knowledge of the molecular variability of WSMV. The data enabled refinement of phylogenetic relationships among WSMV isolates and led to development of an assay for specific detection of a WSMV lineage present in Europe.

\section{MATERIALS AND METHODS}

Virus isolates. The WSMV isolates used in this study are listed in Table 1. All the Czech and Slovak isolates were obtained directly from field samples, without passage in an experimental host plant. The remaining isolates originated from a virus collection kept at the Julius Kühn-Institute, Quedlinburg, Germany. Isolates pv57ASL, the type strain (2), and pv91-ASL (1) were initially purchased from the American Type Culture Collection in 1990. The Agdia isolate was isolated from a positive control sample contained within a WSMV detection kit produced by Agdia (Elkhart, IN). The Turkish isolate was collected by Dr. H. Ilbagi in the Trakaya region of Turkey (16). The Italian and French isolates were collected by Dr. W. Huth (23). WSMV-Toscana was isolated from wheat grown at Colle di val D'Elsa (Tuscany, Italy) and WSMV-Burgund was isolated from wheat near Vezeley (Burgundy region, France). WSMV isolates were propagated by mechanical inoculation to wheat cv. Alcedo and stored as infected leaf material, dried over $\mathrm{CaCl}_{2}$.

RT-PCR and sequence analyses. Systemically infected leaves were used for total RNA extraction using RNeasy Plant Mini Kit (Qiagen, Hilden, Germany). Reverse-transcription polymerase chain reaction (RT-PCR) was performed by RT with pdN6 random primers followed by specific amplification of WSMV cDNA using primers WS8166F (5' GAGAGCAA TACTGCGTGTACG 3', sense) and WS8909R (5' GCATAATGGCTCGAA GTGATG 3', antisense) (18). PCR conditions were initial denaturation at $94^{\circ} \mathrm{C}$ for $5 \mathrm{~min}$, followed by 30 amplification cycles $\left(94^{\circ} \mathrm{C}, 45 \mathrm{~s} ; 53^{\circ} \mathrm{C}, 30 \mathrm{~s}\right.$; and $\left.72^{\circ} \mathrm{C}, 1 \mathrm{~min}\right)$, 
and a final extension at $72^{\circ} \mathrm{C}$ for $10 \mathrm{~min}$. All PCR amplifications were performed using the proofreading TaKaRa Ex Taq polymerase (Takara Bio Inc., Japan). RTPCR yielded a 740- to 743-bp fragment encoding the $\mathrm{N}$-terminus and core region of the capsid protein $(\mathrm{CP})$. PCR products were directly sequenced by priming sequence reactions with the same oligonucleotides as used for PCR. Alternatively, PCR products were inserted into the pGEM-T Easy vector (Promega Corp., Madison, WI) and at least three independent clones per amplicon were commercially sequenced.

Following alignment of sequences with ClustalW, phylogenetic analyses were performed by neighbor joining (26) implemented in Clustal-X or parsimony using PAUP v. $4.0 \mathrm{~b} 10$ (31). Bootstrap analysis with 1,000 replicates was performed to evaluate the significance of tree topology. WSMV CP sequences available in GenBank (http://www.ncbi.nlm.nih.gov) were included in the analysis.

RFLP analysis. PCR product $(3 \mu \mathrm{l}$, amplified using the WS8166F/WS8909R primer set) were digested with ClaI (Promega Corp., Madison, WI) according to the manufacturer's instructions. The ClaI digestion products were assayed on SYBR Green-stained 2\% agarose gels.

\section{RESULTS AND DISCUSSION}

Phylogeny of WSMV isolates from Europe. Although numerous WSMV sequences are available in GenBank, only three are from European isolates. To increase knowledge of genetic diversity of WSMV in Europe, we determined CP sequences of 14 Czech, French, Italian, Slovak, and Turkish isolates. We also determined CP sequences for three additional isolates from North America (Table 1). The sequenced region (699 nt after removal of primer sequences) encompassed almost all of the $\mathrm{CP}$ gene, including both variable and informative regions frequently used in molecular analyses of the Potyviridae family $(7,13,32)$. In case of tritimoviruses, it has been shown that analysis of partial $3^{\prime}$ sequences results in estimates of relationships consistent with that based on complete genome sequences $(24,28)$.

In a preliminary study, maximum likelihood analysis suggested that European isolates may form a distinct subclade (23). In this study, multiple alignments of $\mathrm{CP}$ nucleotide sequences determined here and available WSMV sequences retrieved from GenBank (95 sequences) revealed only limited sequence variation among 3 previously sequenced European isolates and the 14 European isolates described here (average intragroup genetic distance $=1.2 \%$ ) . Moreover, these isolates were characterized by a three-nucleotide deletion (GAG) at nucleotide positions 8,412 to 8,414 (numbered according to the reference Sidney 81 isolate, AF057533). This gap, rewithin the $\mathrm{CP}$ region of the polyprotein, is identical to that occurring in previously characterized isolates (24) from Hungary, AF454456, and AF454459, respectively). This indel represents one of the few gaps in an alignment of the 13 WSMV genomes that have been completely sequenced (AF285169, AF285170, AF454454, AF454455, AF057533, AF511614, AF511615, AF511618, AF511619, FJ348359). Because all European isolates examined lack the $\mathrm{Gly}_{2761}$ codon, we designated this group of European isolates as WSMV- $\Delta$ E. Aside from the $\mathrm{Gly}_{2761}$ deletion common to European isolates, gaps in the complete sequence alignment are limited: a few American isolates lack a single codon $\left(\mathrm{PrO}_{2728}\right)(28,30)$, whereas the divergent El Batán 3 isolate from Mexico (4) has a unique deletion within the $\mathrm{CP}$ region.

Within the region sequenced, WSMV$\Delta \mathrm{E}$ isolates show 97.5 to $99.9 \%$ nucleotide identity to the completely sequenced Czech WSMV isolate, the only European isolate which has been completely sequenced (AF454454; 24). Most WSMV$\Delta \mathrm{E}$ isolates shared $100 \%$ identity when deduced amino acid sequences were compared. Amino acid polymorphism among the European isolates was limited to isolates Czlab, PolickoCRI, SlastJR, and SK512; each differed by one amino acid substitution from the Czech isolate or by two amino acids from the Hungarian isolate (AF454456).

Although the Turkei isolate was most divergent among WSMV- $\Delta \mathrm{E}$ isolates based on nucleotide sequence, its amino acid sequence was identical to the WSMV Czech isolate. Whereas the Turkei isolate described here clustered with European isolates, previously described Turkish isolates (Turkey1 and Turkey2, accession numbers AF454455 and AF454457) clustered with North American isolates (24). sulting in one amino acid deletion $\left(\mathrm{Gly}_{2761}\right)$ Czech Republic, and Russia (AF454454, AF511630, AF511643, FJ348358, and

These data indicate coexistence of two distinct WSMV genotypes in Turkey. Interestingly, isolate WSMV Turkei sequenced in this study was isolated west of the Bosporus in the European region of Turkey (16). WSMV has not yet been identified from any cereal crop in Germany, although the vector $A$. tosichella (synonym A. tulipae) was reported earlier (22). Accession number AJ889242 was erroneously assigned to a German WSMV isolate by Chen et al. (3). It is necessary to point out that in fact, accession number AJ889242 represents a variant of the North American isolate pv57 (2) which had been maintained in the virus collection of the former Institute for Resistance Research and Pathogen Diagnostics in Aschersleben, Germany.

Phylogenetic relationships determined here confirm that European WSMV isolates constitute a distinct clade with strong bootstrap support (Fig. 1). The same topology has been observed using other algorithms (maximum parsimony and minimum evolution; data not shown). Previous studies grouped WSMV isolates into four distinct clades $(4,24,30)$, with only the European isolates (Czech, Hungarian, and Russian) examined at that time forming a distinct grouping (clade B). Our results confirm this grouping of European isolates into a distinct lineage and considerably extend the available sequence data for this clade. The results further indicate that this monophyletic group of isolates (WSMV$\Delta \mathrm{E})$ is common and widely dispersed throughout the European continent.

Intragroup nucleotide sequence diversity among WSMV- $\Delta \mathrm{E}$ isolates was low $(\pi=$ 0.012 ), whereas divergence within a much larger collection of isolates, mostly from North America (clade D in Stenger et al. [30]) was greater $(\pi=0.031)$. The monophyletic grouping of WSMV- $\Delta \mathrm{E}$ isolates (clade B sensu Stenger et al. [30]) implies a single common ancestor and, presumably, subsequent dispersal throughout

Table 1. List of Wheat streak mosaic virus isolates analyzed in this study

\begin{tabular}{|c|c|c|c|c|}
\hline $\begin{array}{l}\text { Virus } \\
\text { isolate }\end{array}$ & Original host, cultivar & $\begin{array}{l}\text { Year of } \\
\text { isolation }\end{array}$ & Origina $^{a}$ & $\begin{array}{c}\text { Accession } \\
\text { numbers }\end{array}$ \\
\hline CZlab & Triticum aestivum & 2008 & Czech Republic & FJ216408 \\
\hline KosHJR & T. aestivum & 2008 & Czech Republic & FJ216409 \\
\hline PoleR & T. aestivum & 2008 & Czech Republic & FJ216410 \\
\hline Podousy & T. aestivum & 2008 & Czech Republic & FJ216411 \\
\hline Policko-CRI & T. aestivum & 2008 & Czech Republic & FJ216412 \\
\hline KromJR & T. aestivum & 2008 & Czech Republic & FJ216413 \\
\hline SlastJR & T. aestivum & 2008 & Czech Republic & FJ216414 \\
\hline SK344 & T. aestivum, cv. Petrana & 2007 & Slovakia & FJ613358 \\
\hline SK349 & T. aestivum, cv. Karolinum & 2007 & Slovakia & EU723085 \\
\hline SK350 & T. aestivum, cv. Ilias & 2007 & Slovakia & EU723086 \\
\hline SK512 & T. aestivum, cv. Ludwig & 2008 & Slovakia & FJ613359 \\
\hline Burgund & T. aestivum & 2007 & France & FJ606884 \\
\hline Toscana & T. aestivum & 2003 & Italy & FJ606885 \\
\hline Turkei & T. aestivum & 2000 & Turkey & FJ606886 \\
\hline pv57-ASL & T. aestivum & 1990 & ATCC & FJ695512 \\
\hline pv91-ASL & T. aestivum & 1990 & ATCC & FJ695511 \\
\hline Agdia-ASL & T. aestivum? & 2000 & United States & FJ695510 \\
\hline
\end{tabular}

a ATCC = American Type Culture Collection, United States. 


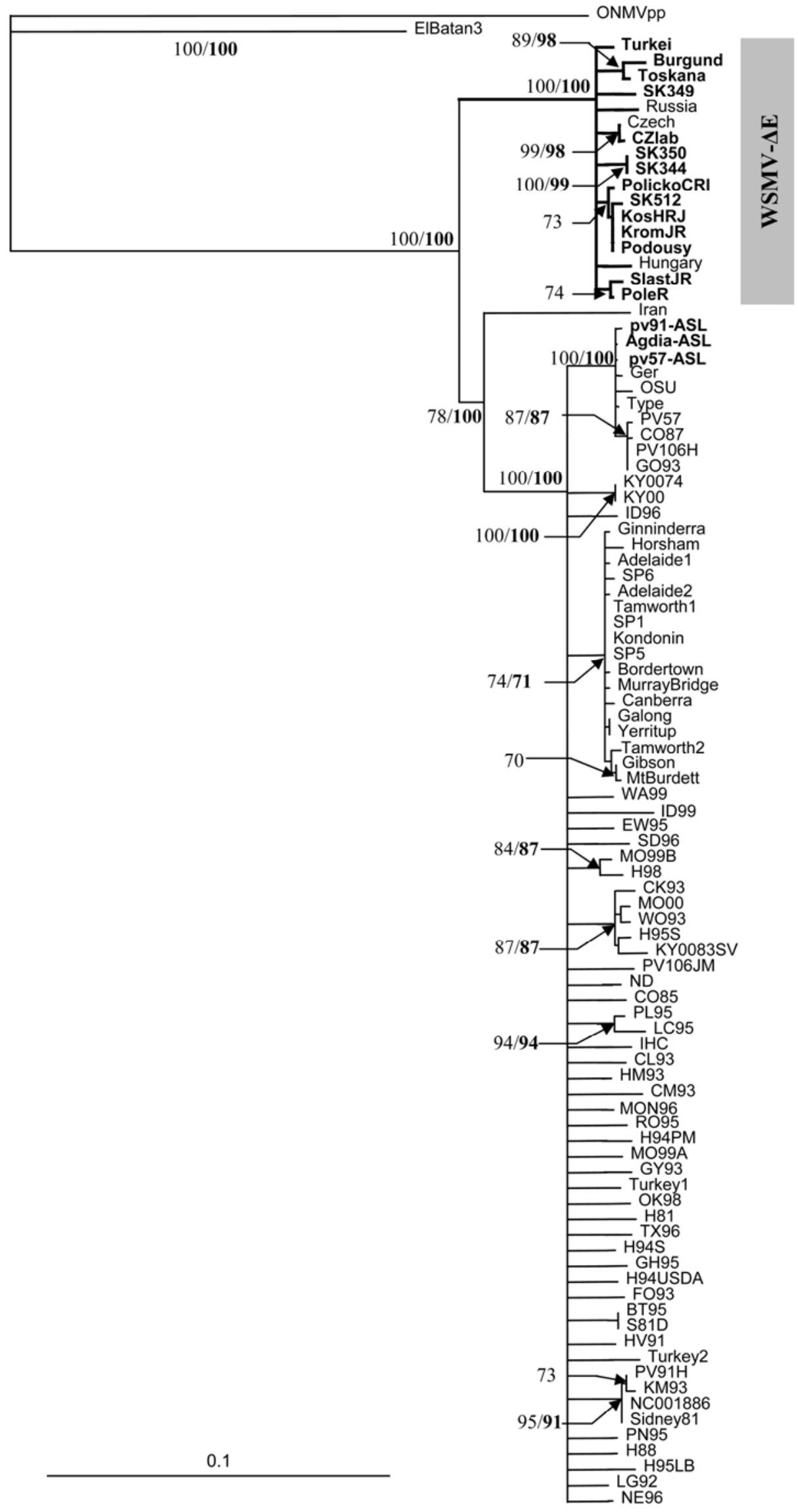

Fig. 1. Phylogenetic tree reconstructed by neighbor-joining method based on alignment of 95 partial Wheat streak mosaic virus (WSMV) sequences (Table 1, http://www.ncbi.nlm.nih.gov). Bootstrap values $>70 \%$ obtained by neighbor-joining method (first number) and parsimony analysis (number in bold) are presented on branches. Nodes bearing bootstrap values $<70 \%$ were collapsed to polytomies. The scale bar represents 0.1 substitutions per site. An isolate of Oat necrotic mottle virus (ONMV-pp; accession number AF454461) was used as outgroup sequence to root the tree. 
Europe from a single focus. Limited variation within WSMV- $\Delta \mathrm{E}$ suggests either strong negative selection pressure, a young population, or a severe bottleneck. Such epidemiological cases have been reported for species of the genera Potyvirus $(8,14)$ and Tritimovirus (28).

Occurrence of the same genotype across the European continent suggests an efficient means of dispersal, probably via human activities (movement of virusinfected material) and subsequent local dissemination by the wheat curl mite vector.

An assay for specific detection of WSMV- $\Delta \mathbf{E}$ isolates. Identification of specific groups of isolates is a preliminary step with respect to development of an efficient disease control strategy and is useful knowledge for successful breeding of resistant cereal cultivars, because screening for resistance requires challenge inoculation with the appropriate isolates of the pathogen resident within the intended area of varietal deployment. Given that WSMV- $\Delta \mathrm{E}$ is the dominant and widespread European genotype, we developed two simple assays for specific and accurate detection of WSMV- $\Delta \mathrm{E}$ isolates.

A multiple-sequence alignment revealed a conserved ClaI restriction site (AT $\downarrow C G A T$, nucleotide position 8,641) located in the center of the $\mathrm{CP}$ gene and unique to $\mathrm{WSMV}-\Delta \mathrm{E}$ isolates. Therefore, a restriction enzyme digestion of the WS8166F/ WS8909R-amplified PCR product using ClaI represents a simple and rapid tool for differentiation of WSMV- $\Delta \mathrm{E}$ isolates (cleavage with ClaI yields two bands of 475 and $266 \mathrm{bp}$, whereas the corresponding amplicon of other WSMV isolates is not cleaved by ClaI; Fig. 2A).

Alternatively, the conserved and specific codon gap in WSMV- $\Delta \mathrm{E}$ sequences was used as a target to design the specific primer WSMspeFw (5' GCCTCGACA CGGGAGCTA $\left.3^{\prime}\right)^{8397-8417}$. When used in combination with WSMspeRv (5' ACC CATCCAGGAAGCAAGG $\left.3^{\prime}\right)^{8736-8754}$, it results in specific one-step RT-PCR detection of WSMV- $\Delta \mathrm{E}$ isolates (Fig. 2B). The RT-PCR was optimized using the One-step kit (Qiagen) as described (19), under cycling conditions of RT at $50^{\circ} \mathrm{C}$ for $30 \mathrm{~min}$ followed by denaturation at $95^{\circ} \mathrm{C}$ for 10 min, 35 cycles of amplification $\left(95^{\circ} \mathrm{C}\right.$ for 30 $\mathrm{s}, 66^{\circ} \mathrm{C}$ for $30 \mathrm{~s}$, and $72^{\circ} \mathrm{C}$ for $1 \mathrm{~min}$ ), and a final extension at $72^{\circ} \mathrm{C}$ for $5 \mathrm{~min}$. The onestep RT-PCR assay yields a 354-bp product when WSMV- $\Delta \mathrm{E}$ templates were used. No amplification product was generated from other WSMV isolates (Fig. 2B).

Nucleotide sequence analysis is ideally suited for obtaining base transition data but

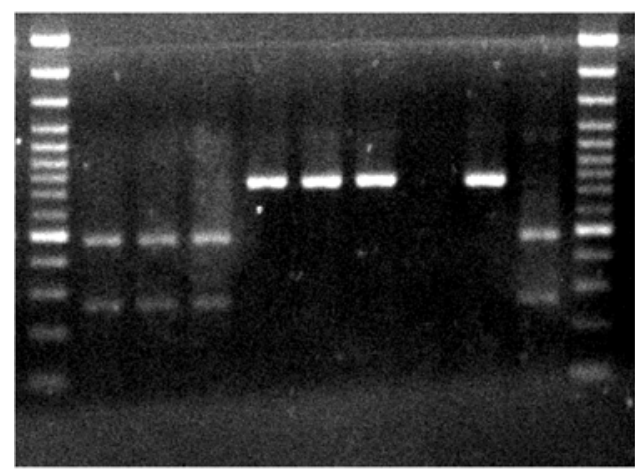

A

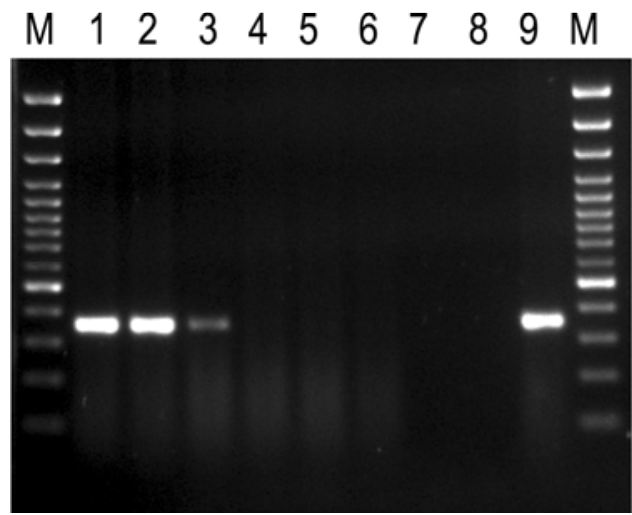

B

Fig. 2. Specific typing and detection of Wheat streak mosaic virus (WSMV)- $\Delta$ E isolates. SYBR Green-stained 2\% agarose gel showing A, restriction fragment length polymorphism profiles of the ClaI-cleaved polymerase chain reaction (PCR) products and $\mathbf{B}$, specific reverse-transcription (RT)PCR detection of WSMV- $\Delta$ E isolates (B). Lanes 1-3: WSMV- $\Delta \mathrm{E}$ isolates (KromJR, Toskana, and Burgund, respectively); lanes 4-6: non-European WSMV isolates (Agdia-ASL, pv57-ASL, and pv91ASL, respectively); lane 7: healthy wheat control; lane 8: A, uncleaved PCR product or B, PCRnegative control; lane 9: the CZlab isolate A, cleaved by ClaI endonuclease or $\mathbf{B}$, detected in RT-PCR; lane M: DNA ladder, 100-bp plus (Fermentas). has been found unsuitable for large-scale testing due to complexity and cost. Therefore, both assays described here provide simple alternative methods for rapid discrimination of WSMV- $\Delta \mathrm{E}$ genotypes that will be useful in efforts to breed resistance to WSMV and in more detailed analyses of the genetic structure and dynamics of WSMV populations.

\section{ACKNOWLEDGMENTS}

This work was supported by the grants VEGA2/7006/27 and VEGA2/0200/09 from the Scientific Grant Agency of Ministry of Education and Slovak Academy of Sciences and by the project MZE 0002700604 of the Czech Ministry of Agriculture. We thank D. C. Stenger, R. French, and H. J. Vetten for their critical reading of the manuscript and valuable comments.

\section{LITERATURE CITED}

1. Brakke, M. K. 1971. Wheat streak mosaic virus. CMI/AAB Descriptions of Plant Viruses, No. 48. Assoc. Appl. Biol., Wellesbourne, UK http://www.dpvweb.net/dpv/showdpv.php?dpv no $=48$

2. Brakke, M. K., Ball, E. M., Hsu Y. H., and Langenberg, W. G. 1987. Wheat streak mosaic virus cylindrical inclusion body protein. $\mathrm{J}$ Gen. Virol. 68:281-287.

3. Chen J., Chen J., and Adams, M. J. 2001. A universal PCR primer to detect members of the Potyviridae and its use to examine the taxonomic status of several members of the family. Arch. Virol. 146:757-766.

4. Choi, I. R., Hall, J. S., Henry, M., Zhang, L., Hein, G. L., French, R., and Stenger D. C 2001. Contributions of genetic drift and negative selection on the evolution of three strains of wheat streak mosaic tritimovirus. Arch. Virol. 146:619-628.

5. Choi, I. R., Horken, K. M., Stenger, D. C., and French, R. 2002. Mapping of the P1 proteinase cleavage site in the polyprotein of Wheat streak mosaic virus (genus Tritimovirus). J. Gen. Virol. 83:443-450.

6. Choi, I. R., Stenger, D. C., Morris, T. J., and French, R. 2000. A plant virus vector for systemic expression of foreign genes in cereals. Plant J. 23:547-555.

7. Desbiez, C., Costa, C., Wipf-Scheibel, C., Girard, M., and Lecoq, H. 2007. Serological and molecular variability of Watermelon mosaic virus (genus Potyvirus). Arch. Virol 152:775-781.

8. Desbiez, C., Joannon, B., Wipf-Scheibel, C., Chandeysson, C., and Lecoq, H. 2009. Emergence of new strains of Watermelon mosaic virus in south-eastern France: evidence for limited spread but rapid local population shift. Virus Res. 141:201-208.

9. French, R., and Stenger, D. C. 2002. Wheat streak mosaic virus. CMI/AAB Descriptions of Plant Viruses, No. 398. Assoc. Appl. Biol., Wellesbourne, UK http://www.dpvweb.net/dpv/showdpv.php?dpv no $=393$

10. French, R., and Stenger, D. C. 2003. Evolution of wheat streak mosaic virus: dynamics of population growth within plants may explain limited variation. Annu. Rev. Phytopathol. 41:199-214.

11. French, R., and Stenger, D. C. 2005. Population structure within lineages of Wheat streak mosaic virus derived from a common founding event exhibits stochastic variation inconsistent with the deterministic quasi-species model. Virology 343:179-189.

12. Garcia-Arenal, F., Fraile, A., and Malpica, J. M. 2001. Variability and genetic structure of plant virus populations. Annu. Rev. Phytopathol. 39:157-186 
13. Glasa, M., Palkovics, L., Komínek, P., Labonne, G., Pittnerová, S., Kúdela, O., Candresse, T., and Šubr, Z. 2004. Geographically and temporally distant natural recombinant isolates of Plum pox virus are genetically very similar and form a unique PPV subgroup. J. Gen. Virol. 85:2671-2681.

14. Glasa, M., Paunovic, S., Jevremovic, D., Myrta, A., Pittnerová, S., and Candresse, T. 2005. Analysis of recombinant Plum pox virus (PPV) isolates from Serbia confirms genetic homogeneity and supports a regional origin for the PPV-Rec subgroup. Arch. Virol. 150:20512060.

15. Hall, J. S., French, R., Morris, T. J., and Stenger, D. C. 2001. Structure and temporal dynamics of populations within wheat streak mosaic virus isolates. J. Virol. 75:1023110243.

16. Ilbagi, H., Yorganci, Ü., Citir, A., and Rabenstein, F. 2003. Occurrence of Wheat streak mosaic virus (WSMV) on cereals in Trakya region in Turkey. J. Turk. Phytopathol. 32:81-89.

17. Jones, R. A. C., Coutts, B. A., Mackie, A. E., and Dwyer, G. I. 2005. Seed transmission of Wheat streak mosaic virus shown unequivocally in wheat. Plant Dis. 89:1048-1050.

18. Kúdela, O., Kúdelová, M., Nováková, S., and Glasa, M. 2008. First report of Wheat streak mosaic virus in Slovakia. Plant Dis. 92:1365.

19. Kundu, J. K. 2003. A rapid and effective RNA release procedure for virus detection in woody plants by reverse transcription polymerase chain reaction. Acta Virol. 47:147-151.

20. Lanoiselet, V. M., Hind-Lanoiselet, T. L., and Murray, G. M. 2008. Studies on the seed transmission of Wheat streak mosaic virus. Australas. Plant Pathol. 37:584-588.

21. McNeil, J. E., French R., Hein G. L., Baenziger P. S., and Eskridge, K. M. 1996. Characterization of genetic variability among natural population of wheat streak mosaic virus. Phytopathology 86:1222-1227.

22. Proeseler, G. 1972. Ein Beitrag zur Morphologie und Ökologie der Gallmilben (Eriophyoidea) an Gramineen. Biol. Zb. Lviv. Derzh. Univ. 91:477-492.

23. Rabenstein, F., Götz, R., Huth, W., and French, R. 2008. Identifizierung und Charakterisierung neuer Viren aus europäischen Weizenherkünften (Identification and characterization of viruses in wheat accessions of European origin). Mitt. Julius Kühn Inst. 417:121-122.

24. Rabenstein, F., Seifers, D. L., Schubert, J., French, R., and Stenger D. C. 2002. Phylogenetic relationships, strain diversity and biogeography of tritimoviruses. J. Gen. Virol. 83:895-906.

25. Rabenstein F., Stenger, D. C., and French R. 2004. Genus Tritimovirus. Pages 398-402 in: Viruses and Virus Diseases of Poaceae (Gramineae). H. Lapierre and P.-A. Signoret, eds. INRA Editions.

26. Saitou, N., and Nei, M. 1987. The neighbor- joining method: a new method for reconstructing phylogenetic trees. Mol. Biol. Evol. 4:406425 .

27. Slykhuis, J. T. 1955. Aceria tulipae Keifer (Acarina: Eriophyidae) in relation to the spread of wheat streak mosaic. Phytopathology 45:116-128.

28. Stenger, D. C., and French, R. 2009. Wheat streak mosaic virus genotypes introduced to Argentina are closely related to isolates from the American Pacific Northwest and Australia. Arch. Virol. 154:331-336.

29. Stenger, D. C., Hein, G. L., and French, R. 2006. Nested deletion analysis of Wheat streak mosaic virus HC-Pro: mapping of domains affecting polyprotein processing and eriophyid mite transmission. Virology 350:465-474.

30. Stenger, D. C., Seifers, D. L., and French, R. 2002. Patterns of polymorphism in Wheat streak mosaic virus: sequence space explored by a clade of closely related viral genotypes rivals that between the most divergent strains Virology 302:58-70.

31. Swofford, D. L. 2002. PAUP*: Phylogenetic Analysis Using Parsimony (*and Other Methods), version 4. Sinauer Associates, Sunderland, MA.

32. Untiveros, M., Fuentes, S., and Kreuze, J. 2008. Molecular variability of sweet potato feathery mottle virus and other potyviruses infecting sweet potato in Peru. Arch. Virol. 153:473-483. 